\title{
New morphological data of Litomosoides chagasflhoi (Nematoda: Filarioidea) parasitizing Nectomys squamipes in Rio de Janeiro, Brazil
}

Novos dados morfológicos de Litomosoides chagasfilhoi (Nematoda: Filarioidea): parasitando Nectomys squamipes no Rio de Janeiro, Brasil

Luís Cláudio Muniz-Pereira'; Paula Araujo Gonçalves²; Erick Vaz Guimarães ${ }^{3}$; Fábio de Oliveira Fonseca²; José Augusto Albuquerque dos Santos ; Arnaldo Maldonado-Júnior ${ }^{5}$; Antonio Henrique Almeida de Moraes Neto

${ }^{1}$ Laboratório de Helmintos Parasitos de Vertebrados - LHPV, Instituto Oswaldo Cruz - IOC, Fundaçáo Oswaldo Cruz FIOCRUZ, Rio de Janeiro, RJ, Brasil

${ }^{2}$ Laboratório de Inovaçôes em Terapias, Ensino e Bioprodutos - LITEB, Instituto Oswaldo Cruz - IOC, Fundaçấo Oswaldo Cruz FIOCRUZ, Rio de Janeiro, RJ, Brasil

${ }^{3}$ Laboratório de Biologia Estrutural - LBE, Instituto Oswaldo Cruz - IOC, Fundaçáo Oswaldo Cruz - FIOCRUZ, Rio de Janeiro, RJ, Brasil

${ }^{4}$ Laboratório de Avaliaçấo e Promoção da Saúde Ambiental - LAPSA, Instituto Oswaldo Cruz - IOC, Fundaçẫo Oswaldo Cruz FIOCRUZ, Rio de Janeiro, RJ, Brasil

${ }^{5}$ Laboratório de Biologia e Parasitologia de Mamíferos Silvestres Reservatórios - LBPMSR, Instituto Oswaldo Cruz - IOC, Fundação Oswaldo Cruz - FIOCRUZ, Rio de Janeiro, RJ, Brasil

Received September 5, 2016

Accepted September 26, 2016

\begin{abstract}
Litomosoides chagasfilhoi, originally described by Moraes Neto, Lanfredi \& De Souza (1997) parasitizing the abdominal cavity of the wild rodent, Akodon cursor (Winge, 1887), was found in the abdominal cavity of Nectomys squamipes (Brants, 1827), from the municipality of Rio Bonito, Rio de Janeiro State, Brazil. This study led to addition of new morphological data and a new geographical distribution for this filarioid in Brazil. Several characters were detailed and emended to previous records of $L$. chagasfilhoi in $N$. squamipes, and confirming the original description in $A$. cursor: buccal capsule longer than wide with walls thinner than the lumen, right spicule slightly sclerotized, with membranous distal extremity slender, with a small tongue-like terminal portion, left spicule with handle longer than the blade, whose edges form large membranous wings folded longitudinally.
\end{abstract}

Keywords: Nematoda, Filarioidea, Litomosoides chagasfilhoi, Rodentia, Cricetidae, Nectomys squamipes.

\section{Resumo}

Litomosoides chagasfilhoi, originalmente descrito por Moraes Neto, Lanfredi \& De Souza (1997) parasitando a cavidade abdominal do roedor silvestre Akodon cursor (Winge, 1887), foi encontrado na cavidade abdominal de Nectomys squamipes (Brants, 1827), no município de Rio Bonito, Estado do Rio de Janeiro, Brasil. Este estudo propiciou a adição de novos dados morfológicos e uma nova distribuiçâo geográfica deste filarídeo no Brasil. Vários caracteres foram detalhados e adicionados ao registro anterior de L. chagasfilhoi em $N$. squamipes, e confirmando a descrição original em $A$. cursor: cápsula bucal mais alta do que larga com paredes mais finas que o lúmen, espículo direito ligeiramente esclerotizado, com extremidade distal membranosa mais estreita, com uma pequena porção terminal em forma de língua, espículo esquerdo com cabo mais longo do que a lâmina, cujas bordas formam grandes asas membranosas dobradas longitudinalmente.

Palavras-chave: Nematoda, Filarioidea, Litomosoides chagasfilhoi, Rodentia, Cricetidae, Nectomys squamipes.

\footnotetext{
*Corresponding author: Antonio Henrique Almeida de Moraes Neto.

Laboratório de Inovações em Terapias, Ensino e Bioprodutos, Instituto Oswaldo

Cruz, Fundaçấo Oswaldo Cruz - FIOCRUZ, CEP 21040-900, Rio de Janeiro,

RJ, Brasil. e-mail: antoniohenrique.moraesneto@gmail.com;

ahmn@ioc.fiocruz.br
} 


\section{Introduction}

The genus Litomosoides Chandler (1931) includes 43 species of parasites of the thoracic and/or abdominal cavities of bats, rodents, and marsupials. Some species have been described from rodents in Brazil, including Litomosoides carinii Travassos, 1919 in Sciurus sp. (Linnaeus, 1758); Litomosoides circularis (von Linstow, 1899) in Holochilus brasiliensis (Desmarest, 1819) (GUERRERO \& BAIN, 2011); Litomosoides silvai Padilha \& Faria, 1977 in Akodon cursor [syn. A. arviculoides (Winge, 1887)] (MORAES et al., 1996); Litomosoides legerae Bain, Petit \& Berteaux, 1980 in Oxymycterus quaestor [syn. O. hispidus (Pictet, 1843)] (BAIN et al., 1980); Litomosoides galizai Bain, Petit \& Diagne, 1989 in Oecomys trinitatis tapajinus (Allen \& Chapman, 1893) (BAIN et al., 1989); Litomosoides kohnae Bain, Petit \& Diagne, 1989 in Nectomys squamipes (Brants, 1827) (BAIN et al., 1989); Litomosoides chagasfilhoi Moraes Neto, Lanfredi \& De Souza, 1997 in A. cursor [syn. A. arviculoides (Winge, 1887)] (MORAES et al., 1997), and Litomosoides odilae Notarnicola \& Navone, 2002 in Oligoryzomys nigripes (Olfers, 1818) according to Simóes et al. (2011).

Litomosoides chagasfilhoi is known to parasitize the abdominal cavities of A. cursor in Rio Bonito (MORAES et al., 1997), and $N$. squamipes in Sumidouro (MALDONADO et al., 2006), Rio de Janeiro State, Brazil. The leading morphological characteristics of this species are as follows: the buccal capsule is higher than it is wide and has walls thinner than the lumen, and the left spicule presents a handle longer than the blade, whose edges form large membranous wings folded longitudinally.

This paper contributes with new morphological data and a new geographical distribution for this filarioid in Brazil.

\section{Materials and Methods}

\section{Studied area and hosts captures}

This study was carried out in Rio Bonito municipality (22 $22^{\prime} 31^{\prime \prime} \mathrm{S}$, $42^{\circ} 36^{\prime} 35^{\prime \prime}$ W, with an altitude of 40 meters), Rio de Janeiro, Brazil, between 2007 and 2011. This locality has small Atlantic Forest fragments on the top of the mountain. The rodents were live-caught in wire-mesh live-traps (Tomahawk ${ }^{\circledR}$ and Sherman ${ }^{\circledR}$ ) placed on the floor along the streams, which is the most important habitat of $N$. squamipes (GENTILE \& FERNANDEZ, 1999). Traps were spaced $10 \mathrm{~m}$ apart, and baited with peanut butter mixed with banana, oat, and bacon on manioc pieces. Captures transects included 50 traps and were conducted during five consecutive days each trapping session.

Rodents were placed in polyethylene boxes measuring $30 \times 18.5 \mathrm{~cm}$, and then asphyxiated with $\mathrm{CO}_{2}$ and necropsied at the local Center of Control of Zoonoses (CCZ), localized in Rio Bonito municipality.

\section{Helminth collection}

The adults of $L$. chagasfilho $i$ were collected from the abdominal cavity during necropsies of twenty naturally infected $N$. squamipes.

For the light microscopy studies, ten adult males and ten adult females of the Litomosoides sp. were washed in a $0.9 \%$ physiological solution and fixed in AFA (the solution contained glacial acetic acid, $37 \%$ formalin, and $70 \%$ ethanol) at $70{ }^{\circ} \mathrm{C}$; they were then washed in distilled water and mounted in lactophenol. The samples were deposited in the CHIOC, preserved in vials with $70 \%$ ethanol.

The drawings were made using a draw tube linked to a Nikon Eclipse E200MV light microscope. The helminths' body length measurements were obtained using a Profile Projector (Nikon GC-2). The measurements are given in micrometers $(\mu \mathrm{m})$, unless otherwise stated.

The adopted classification of the nematodes follows the criteria published by Anderson \& Bain (1976) and Chabaud (1975). Confirmation of the taxonomic status of the host was achieved via karyotype analysis and morphology studies of the skull by Dr. Lena Geise from the Departamento de Genética, Universidade Federal do Rio de Janeiro (UFRJ), Rio de Janeiro State, Brazil.

\section{Imaging analysis}

Images were acquired in a Zeiss Axio Imager.M2 (Carl Zeiss, Germany) equipped with a Plan-Neofluar $40 \times / 1.30$ NA Oil DIC objective lens and Plan-Apochromat 63×/1.40 NA Oil DIC objective lens. The AxioVision software (version 4.8.2, Carl Zeiss) was used to operate the microscope. The images were digitally captured with a charge-coupled device (CCD)-camera (AxioCam HR3, pixel size $6.45 \mu \mathrm{m} \times 6.45 \mu \mathrm{m}, 1388 \times 1040$ pixels). DIC transmitted light images were acquired after setting Köhler illumination using standard DIC optics, and for DIC image acquisition the Nomarski prism bias was kept at the same position to minimize variations. In order to obtain optical sections some images were kept at $0.16 \times 0.16 \mathrm{~mm}$ in the $\mathrm{XY}$ direction and $0.5 \mu \mathrm{m}$ in the $\mathrm{Z}$ direction. The illumination source was Zeiss Colibri light-emitting diode (LED). This multi-user equipment is installed on the Cell Ultrastructure Laboratory of the IOC/FIOCRUZ (Laboratório de Ultraestrutura Celular, IOC/FIOCRUZ).

For the scanning electron microscopy (SEM), the nematodes were fixed in a solution containing $2.5 \%$ glutaraldehyde, $4 \%$ paraformaldehyde, and $5 \mathrm{mM}$ of calcium chloride in $0.1 \mathrm{M}$ sodium cacodylate buffer $(\mathrm{pH} 7.2)$ at room temperature. The samples were later washed three times with $0.1 \mathrm{M}$ sodium cacodylate buffer ( $\mathrm{pH}$ 7.2), postfixed in $1 \%$ osmium tetroxide in $0.1 \mathrm{M}$ cacodylate buffer containing $0.8 \%$ potassium ferricyanide and $5 \mathrm{mM}$ of calcium chloride, washed with cacodylate buffer, dehydrated in ethanol, processed in a Critical Point Dryer with $\mathrm{CO}_{2}$, sputter coated with gold and gold-palladium, and examined using a JSM-6510LV scanning electron microscope at an accelerating voltage of $15 \mathrm{kV}$ at the Plataforma de Microscopia Eletrônica, IOC/FIOCRUZ. 


\section{Ethical aspects}

The collection licenses for the rodents were obtained from the FIOCRUZ Ethical Committee on Animal Use (CEUA L-0015/07) and the Brazilian government's Institute for Wildlife and Natural Resources (Number: 24353-1). All animal procedures followed the guidelines for capture, handling and care of mammals of the American Society of Mammalogy and the bio-security procedures of the Brazilian Health Ministry (LEMOS \& D’ANDREA, 2014).

\section{Results}

\section{Litomosoides chagasfilhoi Moraes Neto, Lanfredi and} De Souza, 1997

General - Bodies of both sexes white, long, slender, cylindrical, and slightly tapered at both ends (Figures 1, 5, 6 and 10). Cephalic end slightly rounded, bearing a simple oral opening, without lips, bounded by a thick rim. Four labial papillae, two cephalic ventral papillae, two well-developed amphids, and a pattern of cuticular striations that formed a labyrinth (Figure 17). Buccal capsule longer than wide, and with symmetric and irregular walls thinner than the lumen. Its posterior extremity is embedded into the bulbous anterior end of the muscular esophagus (Figures 2, 8, 11, 12, 13 and 14) lacking a visible division (Figures 1, 6, and 7).
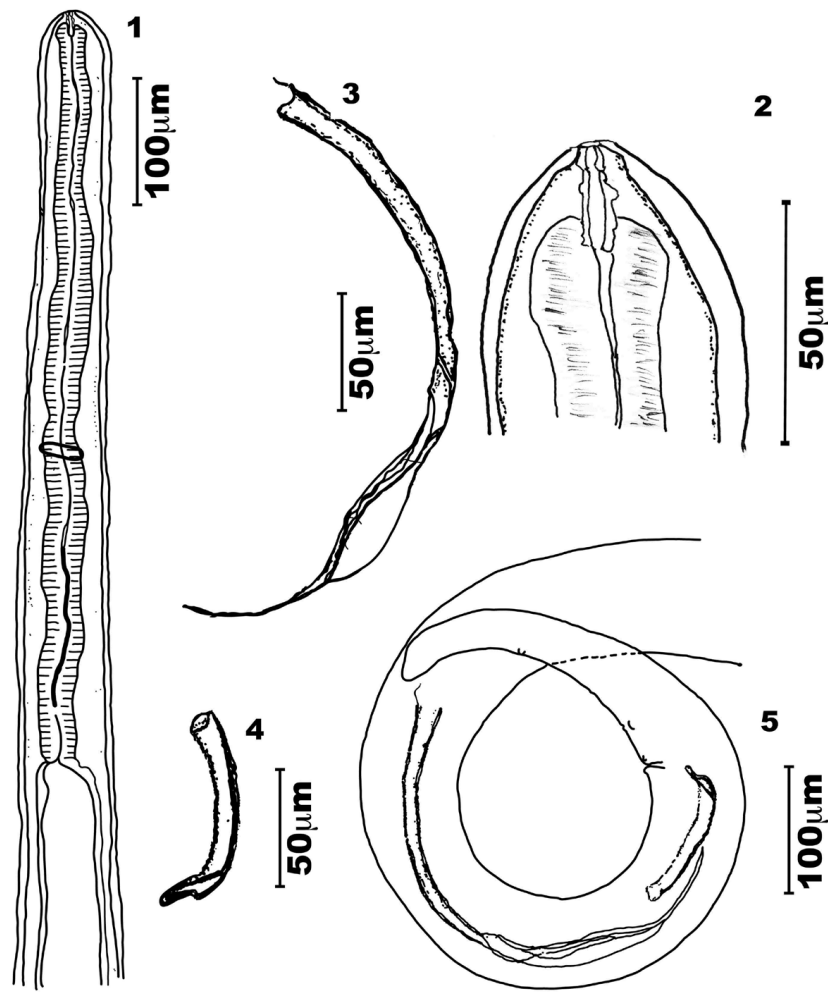

Figures 1-5. Male of Litomosoides chagasfilhoi parasitizing the abdominal cavity of Nectomys squamipes. (1) Anterior region, lateral view; (2) Buccal capsule, lateral view; (3) Left spicule, lateral view; (4) Right spicule, lateral view; (5) Tail with left and right spicules, lateral view.

\section{Males}

Body length 21.9-25.4 mm long, 151.0-163.3 maximum wide. Buccal capsule 19.4-22.2 long, 2.5-5.0 wide; ratio length/width 4.0-6.7. Esophagus 552.3-607.0 long, nerve ring 335.0-358.0 from apex (Figures 1, 2, 11 and 12). Excretory pore not observed. Tail 168.0-238.0 long without caudal alae. Spicules range 315.0-324.0 (left) and 75.0-91.2 (right) spicular ratio $=3.6$; left spicule handle (164.0-185.0) longer than blade, which features a chitinized spindle. Edges of the first half of the blade with large membranous wings, folded longitudinally and easily visible without dissection; wings become narrow in the second half of the blade. Sheath longer than spicule (Figures 3 and 5). Right spicule not well chitinized, and distal region slender with a small tongue-like portion at the extremity (Figures 4 and 5). Cloacal opening ventrally located. Tail with one pair of adcloacal papillae, four to six pairs of postcloacal papillae, and one single papilla near the end of the tail with one single nipple shaped papillae (Figures 5 and 19). Area rugosa with bands of discoid cuticular prominences (Figure 18).

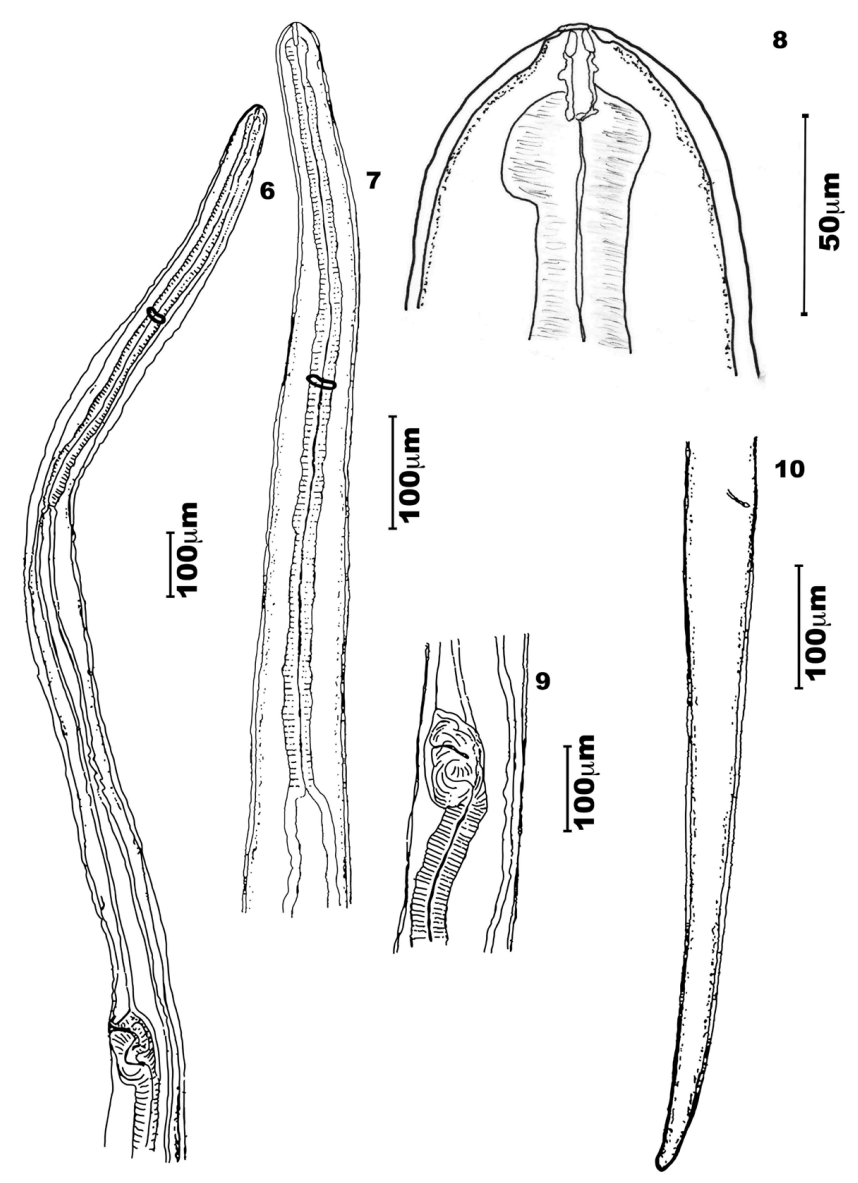

Figures 6-10. Female of Litomosoides chagasfilhoi parasitizing the abdominal cavity of Nectomys squamipes. (6) Anterior region, lateral view; (7) Esophagus region, lateral view; (8) Buccal capsule, lateral view; (9) Vulva, lateral view; (10) Tail, lateral view. 

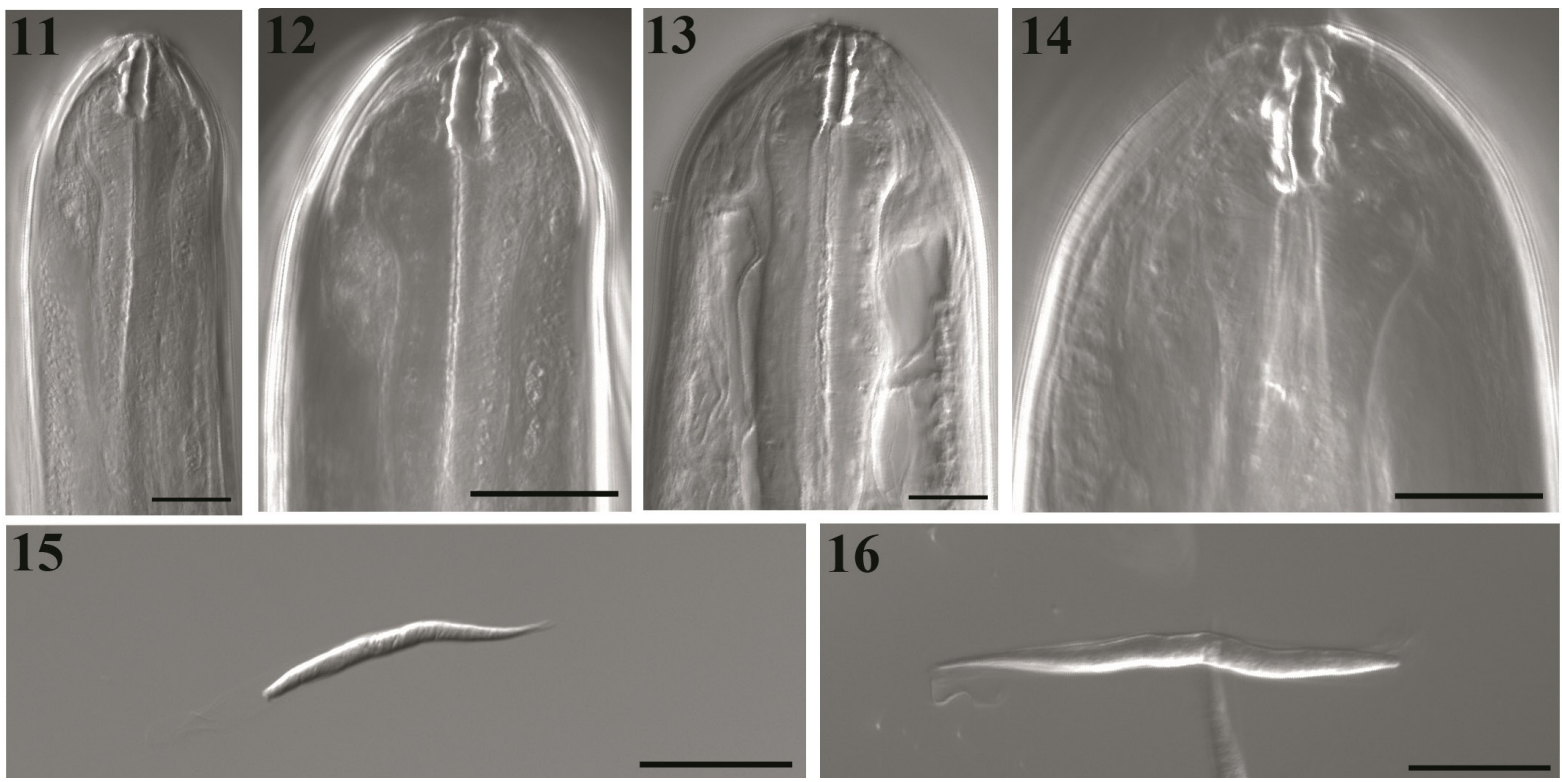

Figures 11-16. DIC transmitted light images of Litomosoides chagasfilhoi from the abdominal cavity of Nectomys squamipes. (11 and 12) Male buccal capsule, median and lateral views, at $40 \times / 1.30$ and $63 \times / 1.40$, respectively; (13 and 14) Female buccal capsule, median and lateral views, at $40 \times / 1.30$ and $63 \times / 1.40$, respectively; (15 and 16) Sequence of optical sections in different plains of microfilariae sheated, lateral view. BARS: $20 \mu \mathrm{m}$.
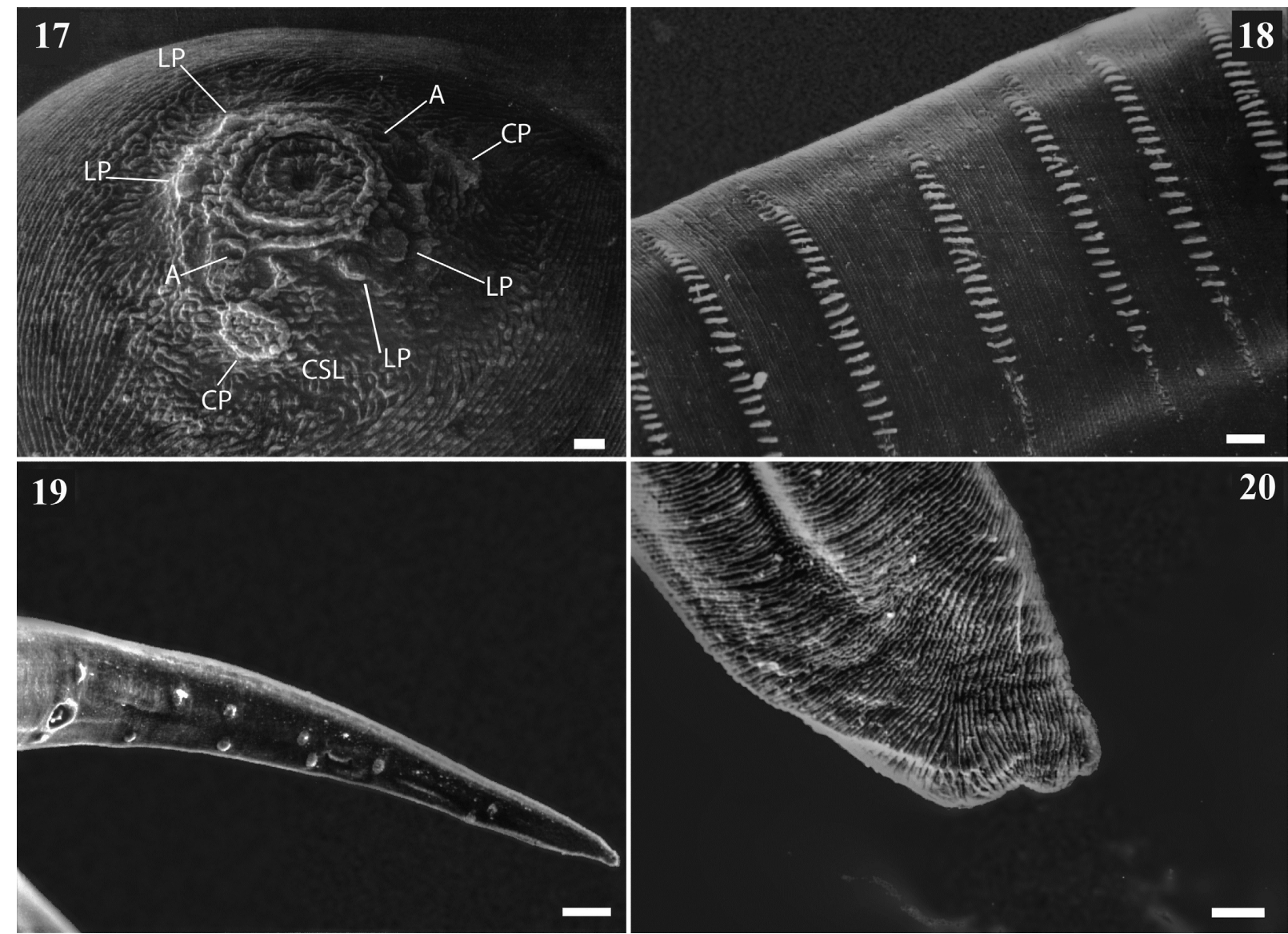

Figures 17-20. Scanning electron microscopy of Litomosoides chagasfilhoi parasitizing the abdominal cavity of Nectomys squamipes. (17) Male en face view of the cephalic end showing 2 cephalic papillae (CP), 4 labial papillae (LP), amphids (A), and cuticular striations forming a labyrinth (CSL). BAR: $1 \mu \mathrm{m}$; (18) Male area rugosa with discoid cuticular prominences. BAR: $2.5 \mu \mathrm{m}$; (19) Ventral view of the tail, adcloacal papillae, postcloacal papillae and one subterminal papilla. BAR: $12.5 \mu \mathrm{m}$; (20) Female caudal end, lateral view. BAR: $2.5 \mu \mathrm{m}$. 


\section{Females}

Body length 78.0-92.4 mm long; maximum width 230.3-330.2. Buccal capsule 19.7-25.3 long, 3.0-5.0 wide (Figures 8, 13 and 14), ratio length/width 4.3-7.3. Nerve ring 360.0-410.0 from apex. Esophagus 621.0-760.0 long (Figures 6 and 7). Tail 390.0-550.9 (Figure 10). Vulva posterior to esophago-intestinal junction (1450.0-1834.0) (Figures 6 and 9) and bordered by one anterior thin lip and a posterior thicker one. Reprodutive tract monodelphic. Uterus opisthodelphic. Anus featured two striated lips, a thin anterior lip, and a thick posterior one. Caudal end rounded (Figure 20) with a pair of phasmids. Viviparous.

Microfilariae: Body fusiform, sheathed, with a salient cephalic hook. Tail attenuated; thin caudal extremity without nuclei. Measurements based on uterine microfilariae from 4 females $(\mathrm{n}=30): 69.1 \pm 6.1(64.1-75.0) \mathrm{mm}$ long, $5.1 \pm 0.7(4.4-5.8) \mathrm{mm}$ wide. Length including sheath 91.3-92.2 (Figures 15 and 16).

\section{Taxonomic summary}

Host type: N. squamipes (Brants, 1827)

Site of infection: Abdominal cavity.

Type locality: Rio Bonito, Rio de Janeiro, Brazil (2242’31”S, 42³6’35” W).

Prevalence: 10\% (2/20).

Mean Intensity: 15 (5 males; 10 females). Rodent 1: 2 males and 5 females; rodent 2: 8 males and 15 females.

Specimens studied: Nine were deposited at the Helminthological Collection of the Oswaldo Cruz Institute (CHIOC), Fundação Oswaldo Cruz, Rio de Janeiro, Brazil (number: 36759a male and $36759 \mathrm{~b}$ female). The following specimens from the authors' collection were used in the description: LG01A-J; LG01K-T.

\section{Discussion}

The analysis of our results led to the conclusion that the species found parasitizing the abdominal cavity of $N$. squamipes from Rio Bonito, Rio de Janeiro, Brazil is indeed L. chagasfilhoi. The referred filarioid species, until now, known to parasitize the abdominal cavity of the rodent $A$. cursor from the same locality and from $N$. squamipes from Sumidouro, Rio de Janeiro (MORAES et al., 1997; MALDONADO et al., 2006).

The filarioids parasitizing $N$. squamipes showed morphological and morphometric similarities to those found in $A$. cursor and emended to previous records of L. chagasfilhoi in $N$. squamipes, when compared to original description. Same variations were observed to: tail length, spicule length, and buccal capsule length. However, the maximum body width differs, showing that the specimens of $N$. squamipes are wider than those of $A$. cursor.

Some species of Litomosoides exhibit low specificity for the vertebrate host, which can be due from a recent speciation among rodents (NOTARNICOLA \& NAVONE 2002). In fact, previous studies stated that $N$. squamipes have been found infected by L. khonae and L. navonae (NOTARNICOLA, 2005). It reinforces our finds which remarks $L$. chagasfilhoi, originally described in A. cursor, as a parasite of the Sigmodontinae rodent, $N$. squamipes.
Therefore, two species of Litomosoides showed a close relationship to our material, but they differ in certain aspects. The first was L. kohnae (= L.carinii SENSU Vaz, 1931) Bain et al. (1989), which presents a right spicule that is not well esclerotized. The right spicule's distal region is cone shaped, sustained by two thin cuticular sticks, ending in a short membranous thong-like structure, generally folded dorsally in the spicule; the tail is often slightly projected. The other species, L. navonae Notarnicola (2005), differs from $L$. chagasfilho $i$ in the following aspects: the anterior region is generally robust, but it is also slender in some specimens. The amphids are slightly salient, featuring a conspicuous channel. There are four externo-labial papillae arranged in a rectangle, and they are aligned dorsoventrally; there is one ventral cephalic papilla. The esophagus is divided, with the glandular portion appearing to be slightly wider than the muscular portion.

One aspect that contributes to this finding is that Litomosoides uses an ectoparasite as vector (BAIN et al., 1989), and that both hosts could share ectoparasites.

In order to clarify the importance of the niche sharing between Litomosoides species, it is necessary additional studies once they can parasitize pleural and/or abdominal cavities.

Thus, the present study led to addition of new data to original description of L. chagasfilhoi and a new vertebrate host record, N. squamipes, in Rio de Janeiro, Brazil.

\section{Acknowledgements}

The authors are grateful to Dr Helene dos Santos Barbosa and Suzana Corte Real Faria, from the Laboratório de Ultraestrutura Celular, IOC/FIOCRUZ, Dr Reinalda Marisa Lanfredi (in Memorian) from the Laboratório de Helmintologia Otto Wucherer and Dr Wanderley de Souza, Laboratório de Ultraestrutura Celular Hertha Meyer, Instituto de Biofisica Carlos Chagas Filho, Universidade Federal do Rio de Janeiro for the teachings; Dr. Lena Geise from the Departamento de Genética, UFRJ, for performing rodent identification, to Dr. Marcelo Knoff for providing access to CHIOC/FIOCRUZ, and to Mitchell Raymond Lishon, Chicago, IL, USA (UCLA 1969) for reviewing and revising the language in this manuscript. This work was supported by Plataforma de Microscopia Eletrônica do Instituto Oswaldo Cruz (IOC), Fundação Oswaldo Cruz (FIOCRUZ), and Conselho Nacional de Desenvolvimento Científico e Tecnológico (MCT-CNPq). English-language editing was provided by Journal Prep.

\section{References}

Anderson RC, Bain O. Keys to genera of the order Spirurida. In: Anderson RC, Chabaud AG, Willmott S. CIH keys to the nematode parasites of vertebrates 3: part 3. London: Commonwealth Agricultural Bureaux; 1976. p. 59-116.

Bain O, Petit G, Berteaux S. Description of two new species and infective stages of filariids of the genus Litomosoides. Ann Parasitol Hum Comp 1980; 55(2): 225-237. PMid:7458160.

Bain O, Petit G, Diagne M. Étude de quelques Litomosoides parasites de rongeurs; conséquences taxonomiques. Ann Parasitol Hum Comp 
1989; 64(4): 268-289. PMid:2817694. http://dx.doi.org/10.1051/ parasite/1989644268.

Chabaud AG. Keys to subclasses, orders and superfamilies. In: Anderson RC, Chabaud AG, Willmott S, eds. CIH keys to the nematode parasites of vertebrates 1: part 1. London: Commonwealth Agricultural Bureaux; 1975. p. 6-17.

Gentile R, Fernandez FAS. Influence of habitat structure on a streamside small mammal community in a Brazilian rural area. Mammalia 1999; 63(1): 29-40. http://dx.doi.org/10.1515/mamm.1999.63.1.29.

Guerrero R, Bain O. Study of types of some species of "Filaria" (Nematoda) parasites of small mammals described by Von Linstow and Molin. Parasite 2011; 18(2): 151-161. PMid:21678791. http://dx.doi.org/10.1051/ parasite/2011182151.

Lemos ERS, D’Andrea PS. Trabalho de campo com animais: procedimentos, riscos e biossegurança. Rio de Janeiro: Editora Fiocruz; 2014.

Maldonado A Jr, Gentile R, Fernandes-Moraes CC, D’Andrea PS, Lanfredi RM, Rey L. Helminth communities of Nectomys squamipes naturally infected by the exotic trematode Schistosoma mansoni in southeastern Brazil. J Helminthol 2006; 80(4): 369-375. PMid:17125546. http:// dx.doi.org/10.1017/JOH2006366.

Moraes AHA No, Lanfredi RM, De Souza W. Emended description of Litomosoides silvai (Nematoda: Filarioidea) of Akodon cursor (Rodentia:
Muridae). J Parasitol 1996; 82(6): 988-991. PMid:8973410. http:// dx.doi.org/10.2307/3284210.

Moraes AHA No, Lanfredi RM, De Souza W. Litomosoides chagasfilhoi sp. nov. (Nematoda: Filarioidea) parasitizing the abdominal cavity of Akodon cursor (Winge, 1887) (Rodentia: Muridae) from Brazil. Parasitol Res 1997; 83(2): 137-143. PMid:9039695. http://dx.doi.org/10.1007/ s004360050223.

Notarnicola J, Navone G. A new species, Litomosoides odilae n. sp. (Nematoda: Onchocercidae) from Oligoryzomys nigripes (Rodentia: Muridae) in the rainforest of Misiones, Argentina. J Parasitol 2002; 88(5): 967-971. PMid:12435138. http://dx.doi.org/10.1645/00223395(2002)088[0967:ANSLON]2.0.CO;2.

Notarnicola J. Description of adult and fourth-stage larva of Litomosoides navonae n.sp. (Nematoda: Onchocercidae), a parasite of five species of sigmodontine rodents from northeastern Argentina. Syst Parasitol 2005; 62(3): 171-183. PMid:16315077. http://dx.doi.org/10.1007/ s11230-005-5490-y.

Simôes RO, Souza JGR, Maldonado A Jr, Luque JL. Variation in the helminth community structure of three sympatric sigmodontine rodents from the coastal Atlantic Forest of Rio de Janeiro, Brazil. J Helminthol 2011; 85(2): 171-178. PMid:20701831. http://dx.doi.org/10.1017/ S0022149X10000398 